\title{
High densities of mushroom coral fragments at West Halmahera, Indonesia
}

Received: 4 February 2010/Accepted: 13 March 2010/Published online: 27 March 2010

(C) Springer-Verlag 2010
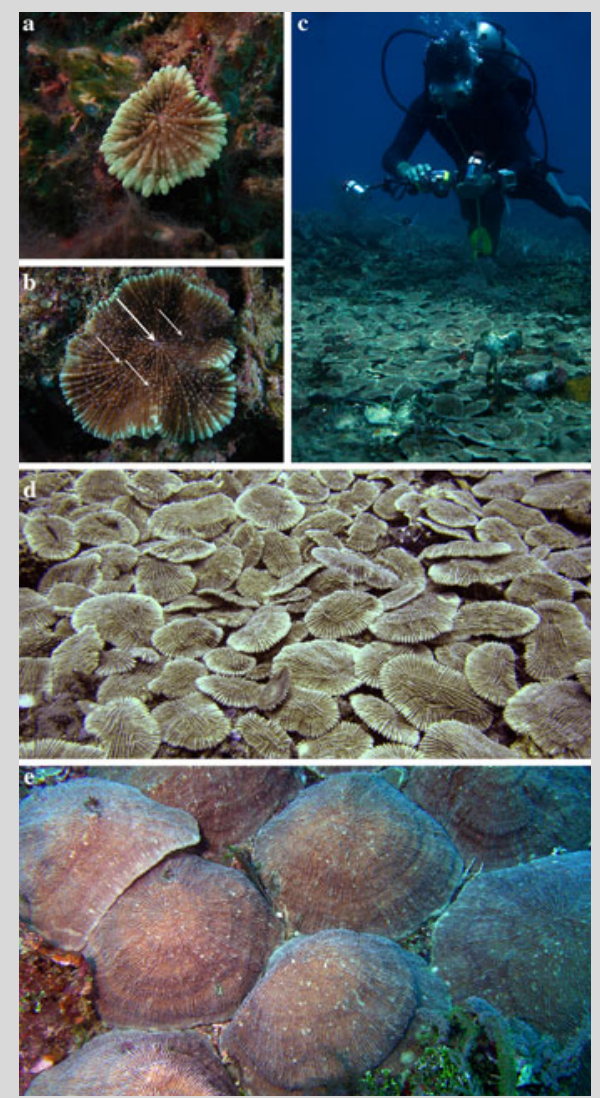

Fig. 1 Halomitra clavator at West Halmahera. a Small $(2.5 \mathrm{~cm})$ anthocaulus showing primary mouth at its centre. b Anthocaulus $(9 \mathrm{~cm})$ with three secondary mouths (small arrows) around the primary mouth (large arrow). c, d Patch of small $(10-15 \mathrm{~cm})$ regenerating fragments. e Cluster of large $(25-40 \mathrm{~cm})$ regenerated corals
The fragile mushroom coral Halomitra clavator Hoeksema, 1989 (Scleractinia: Fungiidae) is known from only a few localities in the central Indo-Pacific (Hoeksema 1989, 1993). It can be distinguished from its more common and widespread congener, $H$. pileus (Linnaeus, 1758), by its thinner corallum, club-shaped septal spines (opposed to sharp), and cream-coloured coral margin (opposed to violet, Fig. 1).

During a biodiversity survey off West Halmahera (northern Moluccas) in $2009, H$. clavator was observed at four out of 39 reef sites $(10 \%)$. This is nearly as common as in Madang Lagoon (Papua New Guinea), where it was found at three sites out of $24(12.5 \%)$, with specimens up to $1 \mathrm{~m}$ in diameter (Hoeksema 1993).

At a submerged reef in Halmahera's Dodinga Bay $\left(0^{\circ} 51.152^{\prime} \mathrm{N}, 127^{\circ} 35.325^{\prime}\right.$ E), several complete corals $(2.5-25 \mathrm{~cm}$ diameter) were found at $18-20 \mathrm{~m}$ depth. These included the smallest $H$. clavator specimens in attached anthocaulus stage ever recorded (Fig. 1a-b). At another site (Guraici I., $0^{\circ} 1.283^{\prime} \mathrm{S}, 127^{\circ} 14.287^{\prime} \mathrm{E}$; 17-22 $\mathrm{m}$ deep), monospecific patches (3-5 m wide) of regenerating mushroom coral fragments were found (Fig. 1c-e). Many were positioned on top of others, resulting in layers of up to three corals and densities of $>100 \mathrm{~m}^{-2}$. This situation is exceptional since previous reports on high concentrations of asexually reproducing mushroom corals concerned less rare species: i.e., H. pileus (Linnaeus, 1758), Zoopilus echinatus Dana, 1846, and Fungia fralinae Nemenzo, 1955 (Pichon 1978; Littler et al. 1997; Hoeksema 2004).

Acknowledgments The survey was sponsored by the Research Centre for Oceanography, Indonesian Institute of Sciences (PPO-LIPI). The research permit was issued by the Indonesian State Ministry of Research and Technology (RISTEK).

\section{References}

Hoeksema BW (1989) Taxonomy, phylogeny and biogeography of mushroom corals (Scleractinia: Fungiidae). Zool Verh Leiden 254:1-295

Hoeksema BW (1993) Mushroom corals (Scleractinia: Fungiidae) of Madang Lagoon, northern Papua New Guinea: an annotated checklist with the description of Cantharellus jebbi spec. nov. Zool Meded Leiden 67:1-19

Hoeksema BW (2004) Impact of budding on free-living corals at East Kalimantan, Indonesia. Coral Reefs 23:492

Littler MM, Littler DD, Brooks BL, Koven JF (1997) A unique coral reef formation discovered on the Great Astrolabe Reef, Fiji. Coral Reefs 16:51-54

Pichon M (1978) Recherches sur les peuplements à dominance d'anthozoaires dans les récifs coralliens de Tuléar (Madagascar). Atoll Res Bull 222:1-447

B. W. Hoeksema $(\bowtie) \cdot$ A. Gittenberger Netherlands Centre for Biodiversity Naturalis, P.O. Box 9517, 2300 RA Leiden, The Netherlands e-mail: Hoeksema@naturalis.nl

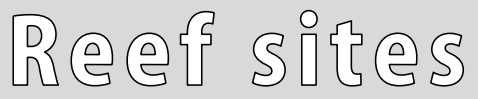

Coral Reefs (2010) 29:691 DOI $10.1007 / \mathrm{s} 00338-010-0616-3$ 